\title{
特殊チャンファ付きダイヤモンドエ具の摩耗抑制をした 高硬度材の超精密マイクロ溝加工*
}

\author{
唐 辛鋭 ${ }^{* *}$ 吉永実樹 ${ }^{* * *}$ 中本圭一 ${ }^{\dagger}$ 石田 徹 $^{\dagger}$ 竹内芳美 ${ }^{\dagger}$
}

\begin{abstract}
Ultraprecision Microgrooving of Hard Materials by Diamond Tool with Special Chamfer to Realize Tool Wear Suppression
\end{abstract}
TANG Xinrui, Miki YOSHINAGA, Keiichi NAKAMOTO, Tohru ISHIDA and Yoshimi TAKEUCHI

Recently, in accordance with the technical development and miniaturization of the information equipments, the demand of optic elements with high precision and miniaturization is increased. The die is used in the manufacture of the optic elements. Thus, it is needed to machine the die with high efficiency and high precision. As the material of mold, hard material including cemented carbide and ceramics is used. However, when hard material is machined, it is a problem of the occurance of brittle fracture and hard tool wear. Tools with chamfer are used in the machining of hard material to reduce tool wear. However, there is a serious problem that the rake angle is not constant along the edge of the conventional R-shape tool with chamfer since the tool shape is like ellipse, it is difficult to machine hard materials with high precision. To solve this problem, a special tool with chamfer is developed. The study proposes a new microgrooving method with tool wear suppressed by the special tool with chamfer. The effectiveness is verified by the microgrooving experiment of $\mathrm{SiC}$.

Key words: ultraprecision microgrooving, hard material, R-shape diamond tool with chamfer, tool wear suppression, cutting point swivel machining

\section{1. 序}

近年, 各種情報機器の高性能化・小型化に伴い, それらを支 える基幹部品である光学素子に対して, 高精度化・高機能化が 要求されている.レンズなどの光学素子は, 金型で成型して量 産されるため, 金型は特に高精度化の要求が高い.

レンズの素材として, プラスチックは低コストと低成型温度 というメリットをもっているため, 多用されてきたが, 近年で は, 優れた光学特性をもっているガラスの使用が増えている. しかしながら, ガラスの成型温度は高く, それに耐えうる金型 が必要になる. 高硬度かつ耐熱性のある金型材料として, 超硬 合金やセラミックスなどの硬脆材料が挙げられる.

従来の硬脆材料は, 一般にマシンニングセン夕等で荒加工を した後に, 放電加工と研磨加工を行っている。しかし, 微小形 状の金型を製作する場合, 放電加工では電極の製作が困難であ り,さらに, 放電加工によって金型の形状が崩れる可能性があ る.また, 研磨加工では, 複雑形状に対して形状精度を落とさ ないで良好な加工面を得ることが困難である。

このような問題を解決するために, 最終仕上げはダイヤモン ド工具による切削加工で対処することが多くなっているが, 高 硬度材料の切削にともない, 激しい工具摩耗が発生する. 摩耗 した工具形状は加工面に転写されるので, 高精度な加工を長時 間継続することは難しい.

この工具摩耗は, チャンファ付き工具を使用することで抑制 できることが知られている.チャンファ付き工具とは, 図1に 示すように, R型工具のすくい面に小さな面取りをし、負のす

* 原稿受付 平成 21 年 11 月 6 日

** 学生会員 大阪大学大学院(大阪府吹田市山田丘 2-1)

*** 株式会社アライドダイヤモンド(兵庫県加東市河高黑石 1816-174)

$\dagger$ 正 会 員 大阪大学大学院(大阪府吹田市山田丘 2-1)
くい角と鈍角の先端角をもつ工具である. しかし, 図1(a)に示 すように, 従来のチャンファ付き工具は, 単純に工具の先端の

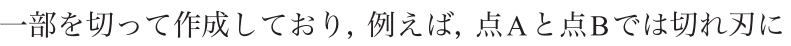
垂直な面とチャンファの角度が同じではなく, 切れ刃全体にお けるすくい角は不均一になる。この結果, 切りくずの形態が変 わり, 被削物の面粗さに影響を与える.ささらに, 切れ刃形状が 楕円状であるため, 特に円弧補間を使用した場合に形状誤差が 生ずるといった問題がある.

これらの問題を解決するために, 図 1(b)に示すような特殊 チャンファ付き工具が開発されている ${ }^{1)}$.この工具は切れ刃に 沿って, 垂直断面の角度が一定となるすくい角をもっている. これによって,すくい角と工具長さの変動を回避できる.また, 円弧状の切れ刃形状のため, 円弧補間を使用しても精度が落ち ないという利点がある.

そこで本研究では, この新しい特殊チャンファ付き非回転 $\mathrm{R}$ 型工具を用い, 工具摩耗を抑制しながら高硬度材料を高精度加 工できる方法の開発を目的としている. そのため, 断面が円弧

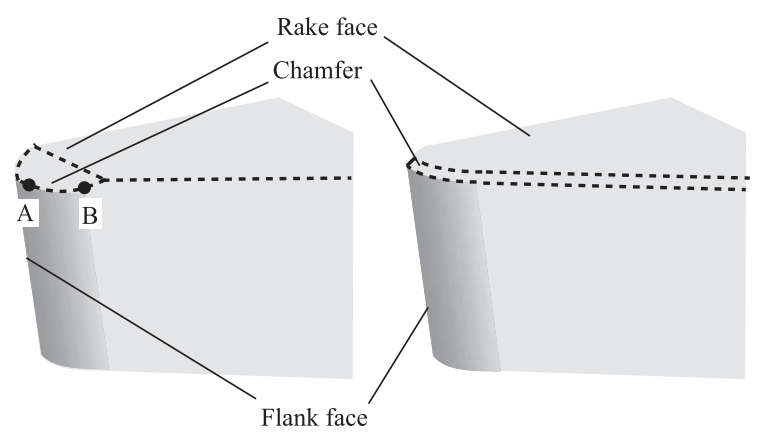

(a) Conventional type (b) New type

Fig.1 Tool with chamfer 
状のマイクロ溝加工を行い, 特殊チャンファ付き工具の効果を 確認し，提案する新加工法の効能を検証する。

\section{2. 超精密加工機および使用工具}

本研究で用いる超精密加工機(FUNUC 製 ROBOnano)の構造 を図 2(a)に示す。この加工機は $\mathrm{X}, \mathrm{Y}, \mathrm{Z}$ の並進軸 3 軸， B， C の回転軸 2 軸の同時 5 軸制御加工が行える. 各軸の最小分解能 は並進軸で $1.0 \mathrm{~nm}$ ，回転軸で $1 \times 10^{-5} \mathrm{deg}$ である，また，図2(b)に 示すように, B軸に回転制御可能なA軸を取り付けることによ り，6軸加工を実現できる.

使用する特殊チャンファ付き工具は, 図3に示すように先端 部半径が $0.1 \mathrm{~mm}$ のバイトの単結晶ダイヤモンド工具( 株式会 社アライドダイヤモンド製超精密切削工具「UPC」)である。こ の工具は刃先に均一なチャンファが付けられており, そのチャ ンファの幅は1〜 $5 \mu \mathrm{m}$ である. 硬脆材料の加工では, 脆性破壊 を抑えるため，一般には切込み深さを数百 $\mathrm{nm}$ 程度で行う，こ の特殊チャンファ付き工具を用いる加工では, 図4に示すよう に, チャンファの部分だけで行うため, チャンファの角度がす くい角になる.

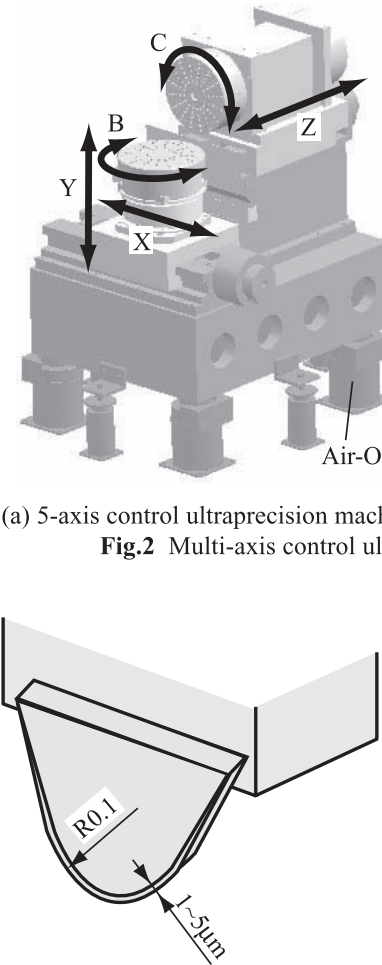

Fig.3 Tool with chamfer

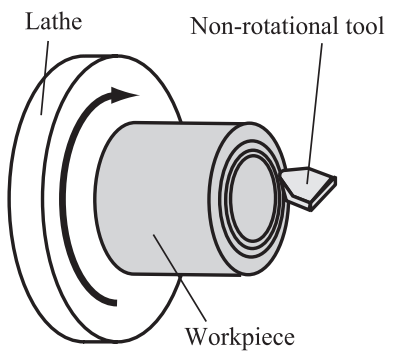

(a) Turning operation

Fig.5 Microgrooving

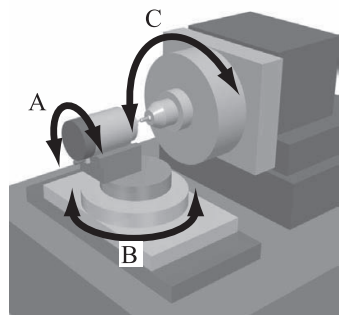

(b) A-axis mounted on B-axis mper

\section{enter}

aprecision machining center

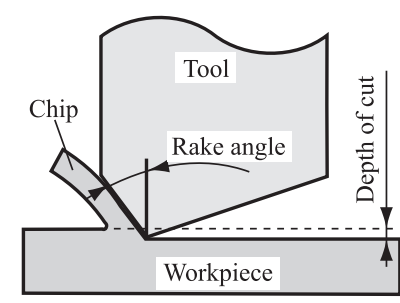

Fig.4 Machining by tool with chamfer

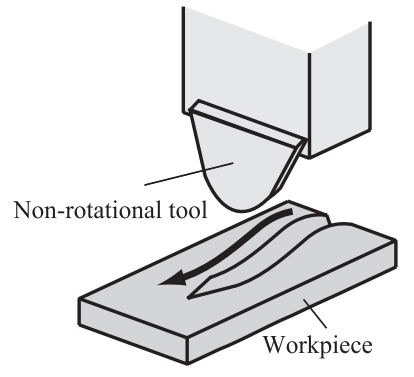

(b) Shaping operation

\section{3. 最適すくい角に関する実匰}

硬脆材料の加工では, 脆性破壊によって良好な仕上げ面を得 られなくなりがちであるが, 切込み深さを小さくすることによ り抑制できる2)-6). 脆性破壞が発生しない最大の切込み深さは, 臨界切込み深さと呼ばれる. 臨界切込み深さはすくい角に依存 しており, 臨界切込み深さが最大值を取るときのすくい角を最 適すくい角と呼ぶ. 高効率な加工を実現するためには, 最適す くい角での加工が望まれる.

これまでに, 臨界切込み深さ及び最適すくい角に関する様々 な研究が行われてきた。単結晶ダイヤモンド工具を用いた超精 密切削加工では, シリコンやゲルマニウムの臨界切込み深さと 最適すくい角を評価する研究が行われている7-9). また, BK7 と 低熱膨張ガラスの切込み実験 ${ }^{10)}$ 及びF2 ガラスに対する工具す くい角による影響11)も調査されている.さらに, 傾斜プランジ カットによるシリコン, ゲルマニウムの切込み実験 ${ }^{12}$, 円弧切 削加工機によるガラスの臨界切込み深さに関する研究13も行わ れている.

しかし, その多くの研究は旋削加工に関するものである.旋 削加工は, 図 5(a)に示すように同心円状の溝加工しかできな い. 光学素子の複雑化の要求により, 図5(b)に示すように, 工 具経路を制御することで様々な曲線を加工できるシェーパ加工 の使用が多くなっているが,この引切り工具についての研究は 行われていない. また, 被削材ごとに臨界切込み深さ及び最適 すくい角も異なるが, これまでの研究はシリコン, ゲルマニウ ム及びガラスに対するものがほとんどであった. 近年, ガラス 金型の要求から注目されている高硬度, 而摩耗性かつ耐熱性を もつ $\mathrm{SiC}$ に関する研究は少ない.

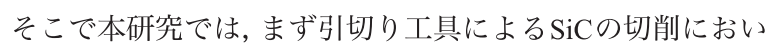
て, 最適すくい角を調べるための実験を行った. 工具はチャン ファが付いていない市販の工具を用いた．図6(a)に示すよう に, B 軸テーブル上に被削材を設置し, C軸上に工具を取り付 け，X方向に工具を送るようにセッティングを行った。このと き, 図6(b)に示すように, C軸をマイナス方向に $\alpha$ 度回転させ ることで, 工具のすくい角を変更することができ, そのすくい 角は- $\alpha$ 度となる. 図7に加工形状を示す. 水平方向の移動距離 $3 \mathrm{~mm}$ に対して, 垂直方向の変位が $300 \mathrm{~nm}$ の傾きをもつ溝であ る. 図8は加工された溝の模式図を示すが, 脆性破壊が発生し

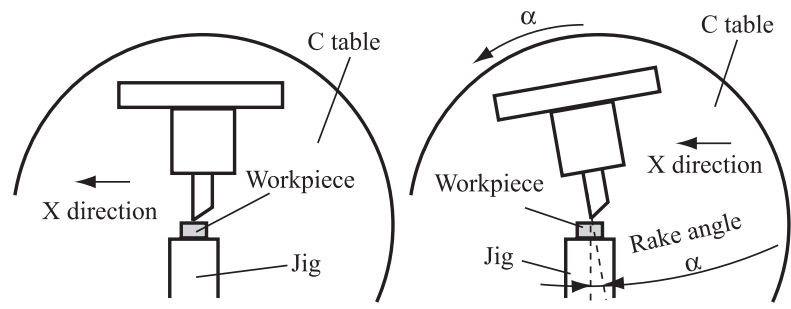

(a) Without rotation (b) Minus rotation by $\alpha$ degree Fig.6 Change in rake angle by the rotation of $\mathrm{C}$-axis

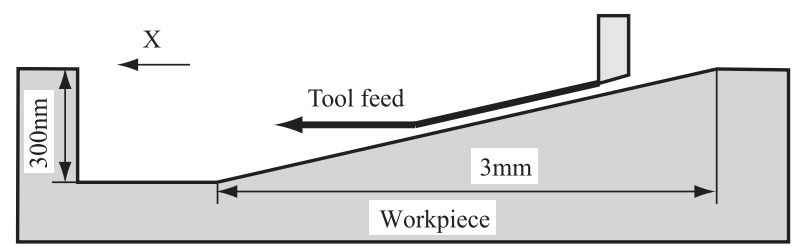

Fig.7 Machining experiment to determine the best rake angle 


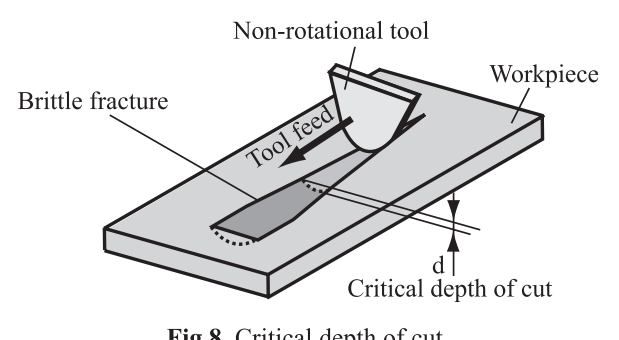

Fig.8 Critical depth of cut

Table 1 Cutting condition

\begin{tabular}{c|r}
\hline Workpiece & $\mathrm{SiC}$ \\
\hline Max depth of cut & $300 \mathrm{~nm}$ \\
\hline Rake angle & $-10,-20,-30,-40,-50 \mathrm{deg}$ \\
\hline Feed rate & $0.5 \mathrm{~mm} / \mathrm{min}$ \\
\hline Grinding fluid & Oil mist \\
\hline
\end{tabular}

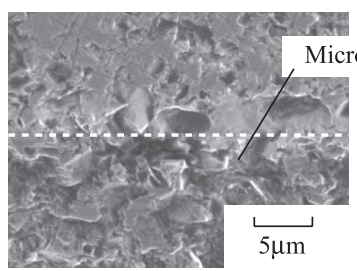

(a) Brittle mode

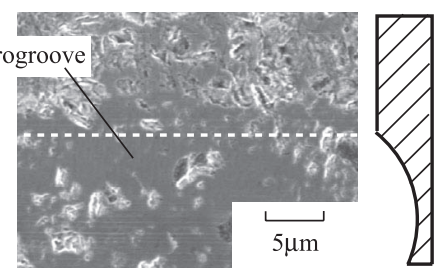

(b) Ducile mode

Fig.9 Microgrooving experiment of $\mathrm{SiC}$

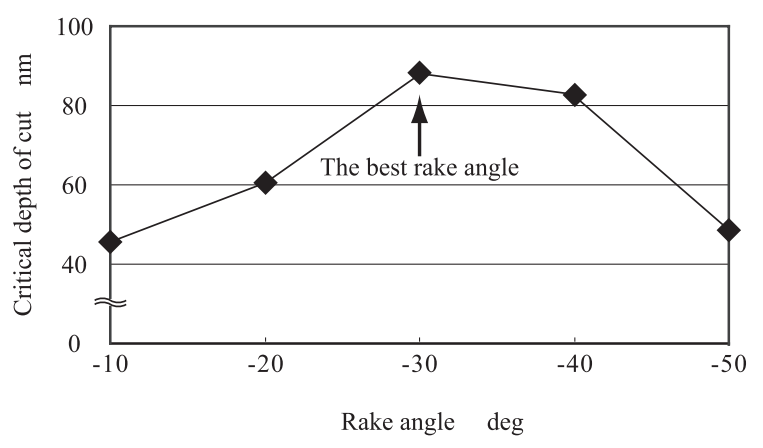

Fig.10 Relationship between rake angle and critical depth of cut

始める地点での溝の深さdが臨界切込み深さとなる。すくい角 を様々に変化させ, 臨界切込み深さが最大になるときのすくい 角を最適すくい角とする.

すくい角を-10度から 10 度ずつ変化させ, 図7に示す溝加工 を行った. 加工条件を表 1 に記す. 図9には加工結果の一例を 示す. 白線よりも下の部分は加工された溝であり, (a) は脆性破 壊を発生している脆性モード加工の一例で, (b) は延性モード 加工である. 溝加工開始地点から脆性破壊が発生した地点まで の距離に基づき,各すくい角での臨界切込み深さを計算したも のを図 10 に示す。測定器はZygo 社製 NEW VIEWである。す くい角が-10度から -30 度までの間では，すくい角が負に大き くなると, 臨界切込み深さが大きくなり，-30度のときに最大 の $88 \mathrm{~nm}$ になる。 また, すくい角が -40 度のとき, 臨界切込み 深さは $83 \mathrm{~nm}$ となり, すくい角が -30 度のときに比べてやや小 さい.さらに, すくい角が-50度になると, 臨界切込み深さが 急激に浅くなり, 溝加工中に被削材の表面部は塑性変形が生 じ，また，深層部は弾性変形が生じている，すくい角が負に大 きくなると, 臨界切込み深さが浅くなる理由は, 工具刃先の通 過直後に弾性変形が一気に開放され, 塑性変形と弾性変形の境 界部分に残留応力が発生し, 横クラックが生じるためと考えら れる9.

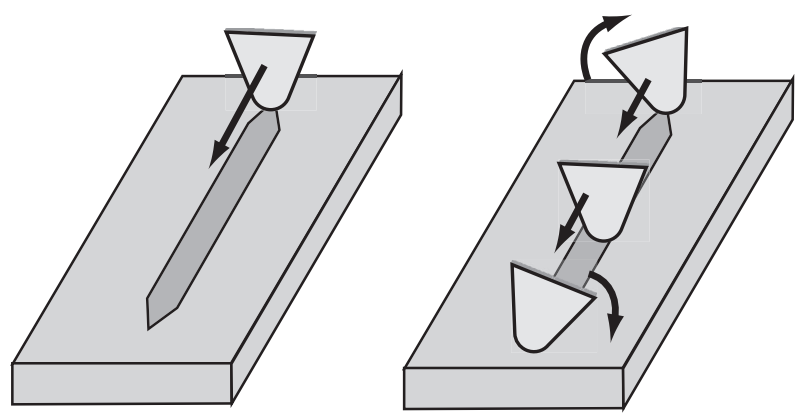

Fig.11 Conventional microgrooving Fig.12 Cutting point swivel machining

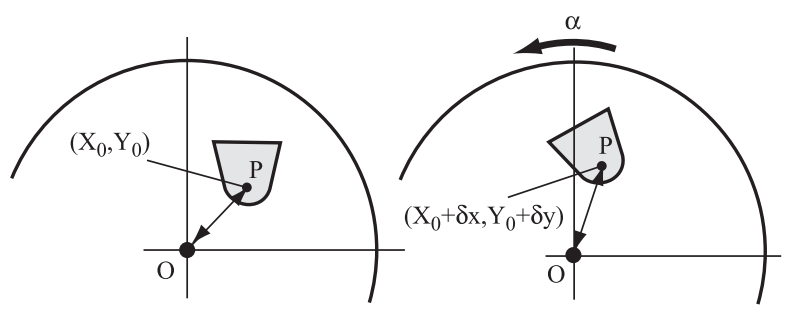

(a) Setting error

(b) Error by rotation of $\mathrm{C}$ table Fig.13 Tool setting error against the center of $\mathrm{C}$ table

以上の結果により，10度ごとのすくい角の変化では-30度の とき, 臨界切込久深さが最大值を取ることが分かった、そこで, 加工中のすくい角が-30度になるように, 使用するチャンファ 付き工具のチャンファの角度を-30度とした。

\section{4. 刃先移動加工法}

\section{1 刃先移動加工法の提案}

図 11 に示すように, 従来の円弧断面の溝加工では, 良好な 表面を得るために, できるだけ工具は同一姿勢を保持しながら 加工を行っている.このとき, 工具は切れ刃の一部のみを使用 して加工するため, 工具摩耗はこの部分に集中する.この問題 を解決するために, 本研究では図 12 に示す刃先移動加工法を 提案する. 刃先移動加工法は, 工具は常に進行方向と垂直な面 内に回転しながら加工を行う加工法である. 切削点は切れ刃上 を常に移動し, 切れ刃全ての領域を使って加工するため, 工具 摩耗を抑制し，かつ平均化することが期待できる.

刃先移動加工法の具体的な手順は以下のようになる.

(1) 工具刃先の角度, 工具の先端部半径, 溝の深さなどのパラ メータを用い, 工具に干渉が発生しない回転可能範囲を算 出する.

(2) 目標形状の溝の長さを算出し, 工具の回転可能範囲及び溝 の形状を参照しながら, 溝を微小な領域に分割する.

(3) 分割した領域における工具姿勢を決める.

従来のチャンファ付き工具では刃先形状が棈円状になるた め, 工具を進行方向と垂直な面内で回転させると円弧状の溝で なくなるが, 特殊チャンファ付き工具は円弧状の切れ刃形状を もっているため, 工具を回転させても誤差を生じない.

\section{2 セッティング謓差}

NCデー夕は, 工具を回転させるためのC軸が回転しても, 工 具の中心位置が変わらないように作成されているが, 実際の セッティング作業は手作業であるため, 工具の中心点 $\mathrm{P}$ と C軸 の回転中心 $O$ を一致させるのは難しい. 図13(a)に示すように, 工具の中心点位置 $\mathrm{P}$ の位置を $\left(\mathrm{X}_{0}, \mathrm{Y}_{0}\right)$ とすると, 図 13(b)のよ うに, $\mathrm{C}$ 軸が $\alpha$ 度回転すると, 工具の中心点 $\mathrm{P}$ に変位 $(\delta \mathrm{x}, \delta \mathrm{y})$ が生ずる。この変位は式(1)で表すことができる。 


$$
\left\{\begin{array}{l}
\delta \mathrm{x}=\mathrm{X}_{0} \cos \alpha-\mathrm{Y}_{0} \sin \alpha-\mathrm{X}_{0} \\
\delta \mathrm{y}=\mathrm{X}_{0} \sin \alpha+\mathrm{Y}_{0} \cos \alpha-\mathrm{Y}_{0}
\end{array}\right.
$$

これらの誤差は, 試し加工を行って補正することができる. 図 14 に示すように，C軸を回転させないときと，C軸を $\alpha_{1}$ 度 に回転させたとき, 同じ切込み深さで加工した溝の深さの差 $\mathrm{D}_{1}$ は式(2)で表される。

$$
\mathrm{D}=\mathrm{Y}_{0}-\mathrm{X}_{0} \sin \alpha-\mathrm{Y}_{0} \cos \alpha
$$

従って, 図14に示すように, 同じ切込み深さで3つの工具姿 勢で溝加工を行い, それぞれの差を取って, 二つの連立方程式 を立てることができる。この方程式の解を求めることにより, 工具の中心点位置 $\left(\mathrm{X}_{0}, \mathrm{Y}_{0}\right)$ を求めることができる.

さらに，工具の中心点位置 $\left(\mathrm{X}_{0}, \mathrm{Y}_{0}\right)$ )゙分かれば， $\mathrm{NC}$ データ を式(3)のように補正すればよい.

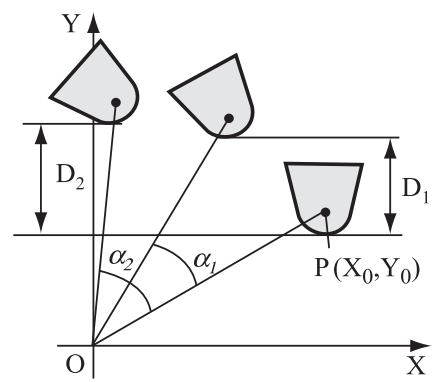

Fig.14 Three kinds of microgrooving to know the actual tool center point

Table 2 Cutting condition

\begin{tabular}{r|c|r}
\hline \multicolumn{2}{|c|}{ WorkPiece } & A5056 \\
\hline \multirow{2}{*}{ Total depth } & Try machining & $10 \mu \mathrm{m}$ \\
\cline { 2 - 3 } & Varification experiment & $5 \mu \mathrm{m}$ \\
\hline \multicolumn{2}{c}{ Depth of cut } & $1 \mu \mathrm{m}$ \\
\hline \multicolumn{2}{c}{ Feed rate } & $40 \mathrm{~mm} / \mathrm{min}$ \\
\hline & Grinding fluid & Oil mist \\
\hline
\end{tabular}

Table 3 Depth of microgroove by the rotation of C table

\begin{tabular}{c|c|c|c}
\hline Rotation of C table (degree) & 0 & 10 & 20 \\
\hline Depth of microgroove $(\mu \mathrm{m})$ & 13.337 & 13.220 & 14.730 \\
\hline
\end{tabular}

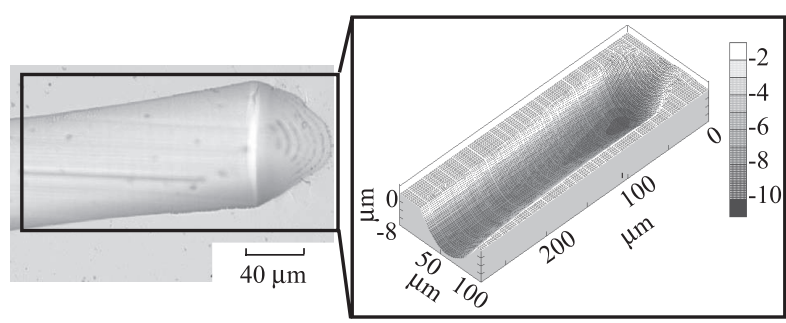

(a) Microgrooving without compensation

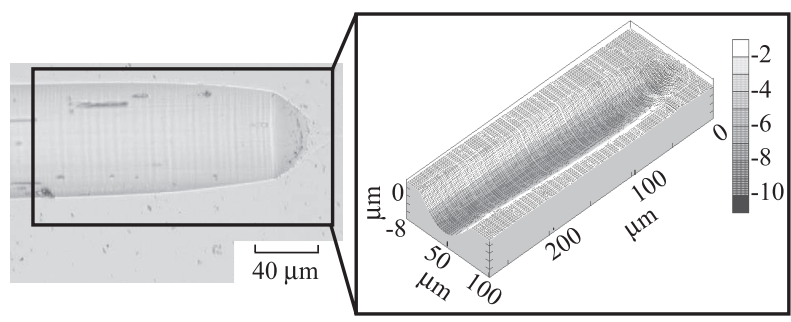

(b) Microgrooving with compensation

Fig.15 Verification experiment of setting error compensation

$$
\left\{\begin{array}{l}
\mathrm{X} \rightarrow \mathrm{X}-\left(\mathrm{X}_{0} \cos \mathrm{C}+\mathrm{Y}_{0} \sin \mathrm{C}\right) \\
\mathrm{Y} \rightarrow \mathrm{Y}-\left(\mathrm{X}_{0} \sin \mathrm{C}+\mathrm{Y}_{0} \cos \mathrm{C}+\mathrm{Y}_{0}\right)
\end{array}\right.
$$

セッティング誤差の補正実験を行い, 効果を確認する.被削 材はアルミニウム系A5056であり．加工条件を表 2 に記す。C 軸を $0,10,20$ 度と変えて固定し，3つの溝加工を行った。 そ れぞれで加工された溝の深さを表3に記す。回転角度と溝の深 さから, 工具の中心点位置は $(-5.348,53.430) \mu \mathrm{m}$ であることが 分かった。この工具中心点位置に基づいて補正加工を行った． 加工条件は表 2 と同じである。

補正前と補正後の加工結果を図15に示す. 測定器には3次元 粗さ測定器(小阪研究所製 SE3500K) を用いる. 補正前の溝で は, 工具の中心点にX方向のセッティング誤差が生じていたた め, 加工した溝は工具の進行方向に対して傾いていることが分 かる. また, 溝の両端は中央部より深くなり, 溝の幅は, 両端 が中央部より広くなっていることが分かる。このような形状に なる原因は, 図 16 に示すように, 工具の中心点位置が $\mathrm{C}$ 軸中 心からわずかであっても誤差をもつと, C軸の回転が原因で変 位が生じるからである。このとき，C軸の回転によって工具中 心点のY方向座標が小さくなり, 加工した溝はC軸の変化がな いときより深くなる。そのため，溝の両端は中央部より深く なっている. また, 工具先端部半径を $\mathrm{R} と し$, 加工した溝の幅 $\mathrm{b}$ と深さ $\mathrm{d}$ の関係は式(4)で表される。溝の両端では中央部より 深いため, 幅も中央部より広くなることが分かる.

$$
b=2 \sqrt{(2 R-d) d}
$$

図 15(b)に示す誤差補正を行った溝は, 工具の進行方向に対 して平行で, 溝全体の深さは均一であることが分る.このよう に，提案した誤差の補正方法の有用性を確認することができ た.

\section{3 刃先移動加工法の検泟実験}

\subsection{1 工具回転可能範井}

提案した刃先移動加工法を用いたときの工具摩耗の低減を確 認するために検証実験を行った. 使用工具は, チャンファの角 度が-30度になる特殊チャンファ付き工具である。

まず，C軸の回転可能範囲を算出した．図17に示すように，

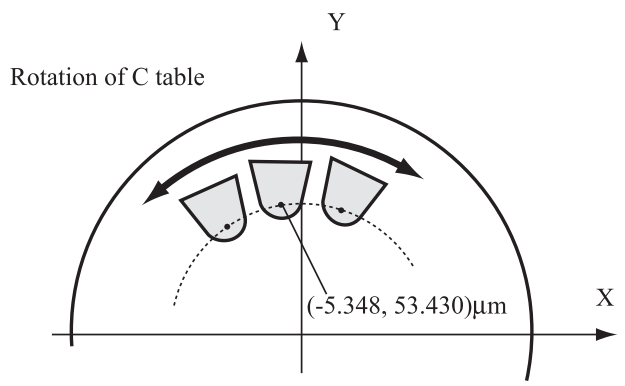

Fig.16 Error induced by the rotation of $\mathrm{C}$ table

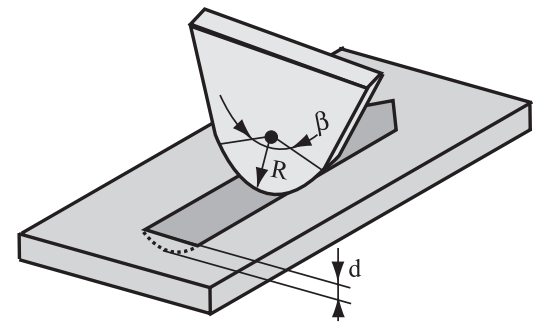

Fig.17 Range of C table rotation 
工具の刃先の角度を $\beta$, 工具の先端部半径を $\mathrm{R}$, 溝深さを $\mathrm{d}$ と すると，工具の回転可能範囲 $\mathrm{C}$ は式(5)で表される.

$$
|C|<\left(\frac{\beta}{2}-\cos ^{-1} \frac{\mathrm{R}-\mathrm{d}}{d}\right)
$$

工具の刃先の角度は $90 \mathrm{deg}$, 工具の先端部半径 $\mathrm{R} は 0.1 \mathrm{~mm}$, 加 工する溝の深さ D は $3.2 \mu \mathrm{m}$ としたため, 工具の回転可能範囲 C は30.466deg となる. また, 切込久深さを $80 \mathrm{~nm}$ としたので, 40 回繰り返し溝加工をする。

本実験では, 工具の回転範囲を-25〜25度に設定し, 加工す る溝の長さは $14 \mathrm{~mm}$ に設定した。この溝の長さ及び工具の回転 可能範囲を考え, 溝を長さ $2.8 \mathrm{~nm}$ の領域に分割した。1領域で の工具の回転角度は 0.00001 度になる. 加工条件を表 4 に示す.

\subsection{2 工具摩耗}

図 18 は從来の加工方法を用いた場合の工具の写真である. (a) は加工前の写真で, (b)は4 本目の溝加工後の工具である. 加 工時間は 15 時間 36 分で, 加工距離は 2240mmである. 図 18(b) に示すように, 加工後のチャンファ部からすくい面にかけて激 しい摩耗が発生したことが分かる.刃先の両端ではほとんど摩 耗が生じていないが，切削に関与している刃先の中心部では チャンファが消失し, 摩耗が集中して生じている.この工具摩 耗により, すくい面の中心部分の破線に囲まれた箇所に凹凹模 様の欠損が生じ, すくい面内で $8 \mu \mathrm{m}$ 程度欠損していることが分 かる.この工具で続けて加工すれば, 工具摩耗により形状精度 が悪化するため, 工具は使用不可能と判断できる.

一方, 刃先移動加工法を使用した工具の写真を同様に図19に 示す. (a) は加工前の写真で, (b) は 8 本目の溝加工後の工具の 写真である. 加工時間は 31 時間 12 分で, 加工距離は $4480 \mathrm{~mm}$ である。図19(b)に示すように, $2 \mu \mathrm{m}$ 程度のチャンファ部に均 一な摩耗が発生して幅が狭くなるものの, すくい面には摩耗に

Table 4 Cutting condition

\begin{tabular}{c|r}
\hline Workpiece & $\mathrm{SiC}$ \\
\hline Total depth & $3.2 \mu \mathrm{m}$ \\
\hline Depth of cut & $80 \mathrm{~nm}$ \\
\hline Feed rate & $3 \mathrm{~mm} / \mathrm{min}$ \\
\hline Grinding fluid & Oil mist \\
\hline
\end{tabular}

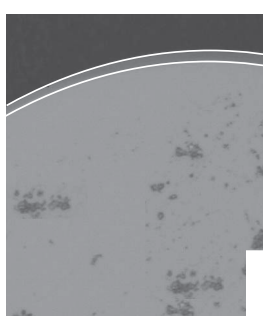

(a) Before machining Fig.18

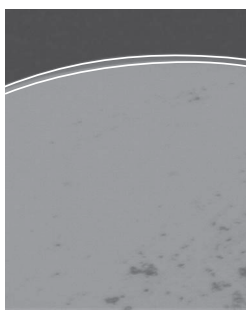

(a) Before machining Fig.19 Tool wear by cutting point swivel machining

よる凹凹が見られない. 工具の刃先形状が円弧状であり, 続け て加工しても形状精度を保てると考えられる. 従って, 従来の 加工方法に比べて, 加工距離が 2 倍になっても摩耗は抑制され ることから, 刃先移動加工法は従来の加工方法と比べて工具の 寿命を2倍以上に伸ばすことができると考えられる.

4.3.3 加工溝の表面粗さ

従来の溝加工法で加工された溝を図 20 に示す. (a)は1本目, (b)は4本目の溝の写真である.被削材にはポアレス処理が行わ れていないため, 溝表面に気孔が見える. 加工された溝表面に は切削痕が見えるため, 延性モードでの加工であったことが分 かる. また, 図21に刃先移動加工法で加工された溝を示す. (a) は 1 本目, (b)は 8 本目の溝写真である.

図 22 に両加工法における工具進行方向の表面粗さ $(\mathrm{Rz})$ の遷 移を示す. 従来の溝加工法で加工した 1 本目と4本目の溝の表 面粗さはそれぞれ $97 \mathrm{~nm}$ と 207nmであった。1本目の溝は良好 な表面性状を保っているが, これに比べて4本目の溝は表面粗 さが悪化している.この原因は, 工具摩耗が進行し, 摩耗した 工具刃先の形状が加工面に転写されたためと考えられる。ま た, 刃先移動加工法を用いた 1 本目と 8 本目の溝の表面粗さが それぞれ97nm と $127 \mathrm{~nm}$ であった. 1 本目の溝は従来の溝加工 法とほぼ同じ表面粗さをもっていることが分かった. 刃先移動 加工法を用いた場合, 工具姿勢は一定ではないが, 加工された 溝は従来の溝加工法とほぼ同じ表面粗さを実現することができ た.さらに，刃先移動加工法を用いた場合，8本目まで良好な 表面粗さを実現できている。

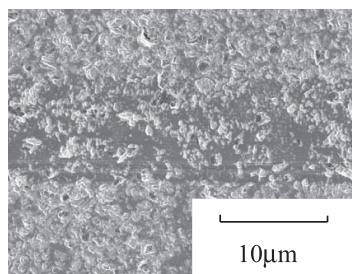

(a) 1 st microgroove

Fig.20 Machined microgrooves by conventional method

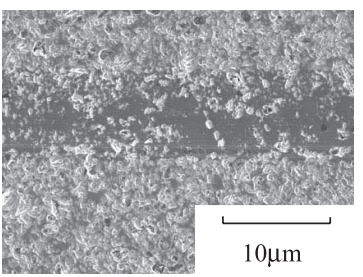

(a) 1 st microgroove

Fig.21 Machined microgrooves by cutting point swivel machining

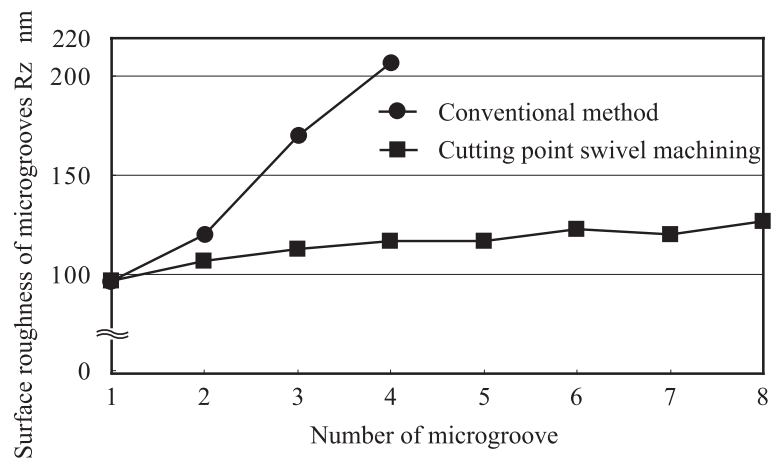

Fig.22 Measured surface roughness $\mathrm{Rz}$ 
また, 同図に示すように, 従来の溝加工法の表面粗さが急激 に悪化するのに対して, 刃先移動加工法を用いた場合の表面粗 さは緩やかに低下している。

以上のことから, 刃先移動加工法は工具摩耗を抑制でき，そ れゆえに, 良好な表面性状をもつ溝が得られることが確認でき た.

なお, 両者の実験で, 全く同じセッティングを実験するのは 困難なため，加工された溝の深さには $200 〜 300 \mathrm{~nm}$ の差があ り, 溝の幅も異なる. 切込み深さは $80 \mathrm{~nm}$ に対して, 3〜4回 の溝加工分に相当するが，全体では 40 回切込むため，影響は 小さいと考えられる.

\section{5.}

本報では, 特殊チャンファ付き $\mathrm{R}$ 型工具を用い, 硬脆材料に 対して, 脆性破壊と工具摩耗を抑制でき, 高効率かつ高精度な 加工を実現することを目的とし, 実験結果から以下の結論を得 ることができた。

(1) 特殊チャンファ付き工具を用い, 工具摩耗を抑制できる刃 先移動加工法を提案した。

(2) 高効率な加工を実現するために, $\mathrm{SiC} の$ 切削における最適す くい角について調べ，チャンファの角度を決めることがで きた。

(3) 加工中におけるセッティング誤差を補正することにより, 高精度な加工を実現できた。

(4) SiCを用い, 提案した刃先移動加工法の加工実験を行い, そ の有用性を証明した。さらに, 刃先移動加工法は工具摩耗 を抑制できるため，良好な表面性状をもつ加工面が得られ ることを確認した。

本研究で使用した $\mathrm{SiC}$ は新日鉄マテリアルズ株式会社よりご 提供頂いた。また, 加工実験に用いた超精密加工機は株式会社 ファナックよりご提供頂いた。記して謝意を表する.

\section{参支 嗝}

1) 小林篤史:超精密ダイヤモンド切削工具「UPC」による最新の金 型加工，型技術， 24，6(2009) 59 .

2) T. Bifano, T. Dow and R. Scattergood: Duticle Regime Grinding: A New Technology for Machining Brittle Materials, ASME, J. Eng. Ind., 113, 5 (1991) 184.

3) T.Sugita, K.Ueda and K.Endo: Possibility of Plastic Deformation Type Removal in Microcutting of Brittle Materials, Journal of Japan Society for Precision Engineering, 52, 12 (1988) 1038. (in Japanese)

4) M. Miyashita: Ductile Mode Grinding Technology for Brittle MaterialsThe Way to Nanogrinding Technology, Journal of Japan Society for Precision Engineering, 56, 5 (1990) 782. (in Japanese)

5) K. E. Puttick, M. R. Rudman, K. J. Smith, A. Franks and K. E. Lindsey: Single-point Diamond Machining of Glasses, Proc. Roy. Soc. A 426 (1989) 19.

6) I. Inasaki: Grinding of Hard and Brittle Materials, Ann. CIRP, 36, 2 (1987) 463.

7) P. N. Blake and R. O. Scattergood: Ductile Regime Machining of Germanium and Silicon, J. Amer. Ceram. Soc., 73, 4 (1990) 949.

8) T. Nakasuji, S. Kodera, S. Hara, H. Matsunaga, N. Ikawa and S. Shimada: Diamond Turning of Brittle Materials for Optical Components, Ann. CIRP, 39, 1 (1990) 89

9) J. Yan, K.Syoji and T. Kuriyagawa: Ductile-Brittle Transition at Large Negative Tool Rake Angles, Journal of Japan Society for Precision Engineering, 66, 7 (2000) 1130. (in Japanese)

10) P. A. Mckeown, K. Carlisle, P. Shore and R.F.J. Read: Ultrapresicion, High Stiffness CNC Grinding Machines for Ductile Mode Grinding of Brittle Materials, Journal of Japan Society for Precision Engineering, 56, 5 (1990) 806

11) 山口 収, 西口 隆, 栘田正美, 内田浩二 : ガラスの臨界切込み 深さに及ぼす工具すくい角の影響, 1990年度精密工学会秋季大会 学術講演会講演論文集, (1990) 751 .

12) E.Brinksmeier, W.Preub and O. Riemer: From Friction to Chip Removal. An Experimental Investigation of the Microcutting Process, Proc. 8th Intern. Prec. Eng. Seminar, (1995) 335.

13) M.G.Schinker: Subsurface Damage Machanisms at High-Speed Ductile Machining of Optical Glasses, Prec. Eng., 13, 3, (1991) 208.

14) M. Sono, T. Ishida, K. Teramoto, T. Enomoto and Y. Takeuchi: General Tool Setting Error Compensation Method for 5-axis Control Ultraprecision Machining, Journal of Japan Society for Precision Engineering, 73, 10 (2007) 1154. (in Japanese) 